\title{
Anti-PD-1 Monoclonal Antibody TSR-042
}

National Cancer Institute

\section{Source}

National Cancer Institute. Anti-PD-1 Monoclonal Antibody TSR-042. NCI Thesaurus.

Code C126799.

A humanized monoclonal antibody directed ag ainst the negative immunoregulatory human cell surface receptor programmed cell death 1 (PD-1; programmed death-1), with potential immune checkpoint inhibitory and antineoplastic activities. Upon administration, anti-PD-1 monoclonal antibody TSR-042 binds to and inhibits PD-1 and its downstream signaling pathways. This may restore immune function through the activation of T-cells. PD-1, a transmembrane protein in the Ig superfamily expressed on T-cells, functions as an immune checkpoint protein that negatively regulates $\mathrm{T}$-cell activation and $\mathrm{T}$-cellmediated immune responses when activated by its ligands programmed cell death receptor ligand 1 (PD-L1) or 2 (PD-L2); it plays an important role in tumor evasion from host immunity. 